\title{
From Responsibility to Citizenship? Corporate accountability for development $^{1}$
}

\author{
Peter Newell
}

'Corporate citizenship can become a significant route for overcoming global poverty, inequality and environmental insecurity' (Zadek 2001:11).

There is now widespread debate about the rights and responsibilities of global corporations. Increasing the language of citizenship is being invoked in order to understand the relationship between rights and obligations. By this device 'Corporations have sought ... to gain broader trust and legitimacy through visibly enhancing their non-financial performance' (Zadek 2001:1). In a partial reading of what citizenship means, emphasis is placed on 'taking account' of social and environmental footprints and constructing 'shared values with key stakeholders' or 'civil partnerships' (Zadek 2001). Taken together, these sentiments recognise that a corporation has 'social, cultural and environmental responsibilities to the community in which it seeks a licence to operate' (CCRU 2001).

This paper seeks to locate contemporary debates about the rights and responsibilities of corporations towards the poor within an understanding of shifting discourses of accountability in development. The first section looks at understandings of accountability historically and their evolution alongside shifts in thinking about the role of key actors in development. This discussion is used to understand the contemporary framings of debates about corporate accountability which have to be located within shifts of political authority taking place in the global economy and the concomitant rise of concern about the balance between the rights and responsibilities of global corporations. The second section interrogates the relationship between accountability and citizenship, with a particular focus on the corporate sector and the way in which early emphasis on the social responsibilities of firms has been eclipsed by claims about their entitlements as citizens. The third section looks at the extent to which notions of corporate citizenship can be meaningfully applied to relations between mobile capital and poor communities. It is suggested that depoliticised notions of 'citizenship as partnership' serve to obscure the power inequities that characterise such relationships. Drawing on examples from North and South where poor communities have been negatively affected by the investment practices of multinational companies, the fourth section suggests the circumstances in which those communities may be able to construct new relations of accountability with corporations.

\section{Traditional conceptions of accountability ${ }^{2}$}

In so far as an enquiry into the practice of accountability in development is de facto an enquiry into how to control the exercise of power, we can view contemporary debates as a continuation of concerns that have driven political philosophy for several hundred years. In contemporary usage, the notion of accountability continues to express this

\footnotetext{
${ }^{1}$ I am grateful to John Gaventa, Jo Howard and Alex Shankland for their comments, and to Carol Spencer for help with assembling the bibliography.

${ }^{2}$ Some of the material in this section draws from Newell and Bellour (2001).
} 
concern with the application of checks and institutional constraints on the exercise of power (Schedler \& Plattner, 1999:14). The term implies both a measure of answerability (providing an account for actions undertaken) and enforceability (punishment or sanctions for poor performance or illegal conduct (Goetz and Jenkins 2001). The prevalent use of the term in recent years can be explained by shifts in the strategic thinking of key development agencies with regard to the state, in particular, and the importance of creating mechanisms of accountability to citizens of the state (Goetz and Gaventa 2001). The predominant focus on state accountability can be understood in the light of prevailing neo-liberal assumptions about the inefficiency and lack of responsiveness of states to the needs of citizens, defined as consumers of services. The rhetoric of public accountability, in turn, is a product of the increasing popularity of new public management approaches and renewed attention to state bureaucracy and administration associated with the 'good governance' agenda pursued by donors.

Recent global trends have however, brought into question the appropriateness of this emphasis on holding governments to account, when their decisions and actions increasingly result from bargains with non-state and private actors. Trends towards privatisation and de-regulation have reconstituted political authority at national and international levels and, as a result, transformed many traditional arenas of accountability. This has brought about a re-negotiation of relations between state and market, out of which has emerged a more complex and dense set of obligations and responsibilities between different actors in the field of development. This has produced both opportunities for the construction of new accountabilities and new 'accountability gaps' when shifts of political authority take place, without the creation of new accountability mechanisms. When private actors perform public functions for example, the issue of responsiveness to the poor is heightened, because they are working to a different mandate: profit maximisation and not service delivery for all.

Mechanisms of accountability can take a diverse range of forms from formal topdown processes of elections, hearings and consultations to bottom- up strategies such as citizen juries or popular protest (Goetz and Gaventa et al 2001). There is a temporal dimension here, where some accountability exercises take the form of one-off events or spectacles which draw attention to a particular abuse of power on the part of the powerful, or are intended $\mathfrak{b}$ demonstrate responsiveness to the public. In South Africa, the Truth Commission, set up to uncover abuses of authority by the government and the police during the apartheid era, would be an example. Other mechanisms of accountability are more institutionalised and ingrained in democratic routine, such as elections and public hearings. In this sense, accountability can be created passively and actively. Constructing new accountabilities, however, assumes both a right and a capacity to articulate accountability demands. There is an important balance to strike, therefore, between building citizen's capacities to articulate rights and the capabilities of politicaleconomic institutions to respond and be held to account (Jones and Gaventa 2001).

Since many conceptualisations of accountability have been derived from ways to improve state mechanisms, the focus of the current debate is still very much linked to state-based notions of answerability and enforceability. Attacks on the efficiency, responsiveness and effectiveness of states in tackling poverty have in many ways prepared the ground for contemporary debates about corporations as development 
actors in providing public goods and forms of welfare provision that states have been unable to (DfID 2000). Concerns remain, however, about the accountability of multinational firms, in particular, to the poor given both the scale of their investments and the social effects of their mobility. These accountability challenges and the way that firms have responded to them are described in the next section.

\section{From accountability to citizenship: The case of Corporations}

It is widely acknowledged that processes of globalisation have served to heighten the power of global corporations (Strange 1996; Scholte 2000), extending corporate influence to activities that have traditionally been the prerogative of states (Newell 2000a:35). With revenues that often dwarf the GDPs of many developing countries, TNCs are often more powerful than governments, and the mobility that allows them to locate their business in the most favourable regulatory environment, gives them a degree of leverage with governments that can be played off against one another. As a result, it often seems that TNCs wield power without responsibility, that they are as powerful as states, yet less accountable (Newell 2000b:36).

Increasingly however, social expectations about the responsibilities of firms far outstrip those that are expressed in legal instruments, where there remains an imbalance between the rights and responsibilities of firms as they are constituted at the global level. The entitlements and rights of corporations are increasingly enshrined in international agreements such as the TRIPs accord and the GATS (General Agreement on Trade in Services). Gill (1995) refers to this as the 'new constitutionalism' in which the rights of capital over states, are affirmed. Each of these agreements affords new rights to companies and circumscribes the powers of national and local authority over investors. For example, the NAFTA agreement allows companies to sue local authorities setting environmental standards that they claim discriminate against foreign companies. Concern lies in the fact that there remains a lack of corresponding emphasis on investor duties, which proved to be a key point of contention in the MAI negotiations (Mabey 1999).

Various concepts have been used to express the rights and obligations that corporations have, to those they work with and work for. 'Corporate governance' refers to the policies and practices used to regulate internal company relationships and fulfil responsibilities to investors and other stakeholders. 'Corporate accountability' is generally invoked to describe the patterns of disclosure, auditing and the monitoring of business practices (Zadek et al 1997), while 'corporate social responsibility' implies a more discretionary act on the part of companies as they consider their role and impact across a wide range of company activities.

The notion of corporate citizenship is another frequently invoked concept, projecting both public purpose and a claim to the entitlements and responsibilities that flow from citizenship. The citizenship that many firms are practising is a partial one, however. Corporations may be attracted to the idea of citizenship because it provides a surrogate for acquiring rights without acquiring new responsibilities. However, many of the traditional notions underpinning the social contract of citizenship, in terms of obligation to a particular community for example, are subverted by the new leverage which firms have acquired as a result of mobility and the threat of relocation on the one hand, and the failure to enforce their responsibilities to the communities in which 
they invest, on the other. The notion of citizenship invokes the idea that firms have an obligation to return something to the communities in which they invest. And yet in the absence of binding regulation to determine the basis of this contract, the range and level of obligations they are expected to undertake is largely open to their discretion. It is this fact that makes their use of the term 'citizenship' highly problematic.

On these grounds, groups have sought to challenge the right of companies to disinvest without obligation to communities. Hathaway (1993) describes the case of the Tristate conference on steel in Pittsburgh which made demands that (i) steel companies be forced to make binding commitments to reinvest some of the wealth they have accumulated from their workers over the years back into existing mills and mill communities (ii) that plants should not be shut down without direct consultation with affected unions and communities (iii) in the event of shutdown, the company must pay the social and human costs of their actions by adequately compensating affected communities. The group's motto was that 'generations of Moll Valley steelworkers have made the steel corporations rich over the years and they just aren't getting up and walking away' (Hathaway 1993:92). The importance of reciprocal obligations and two-way accountability to a meaningful notion of corporate citizenship is developed in the next section.

\section{Limits of corporate citizenship: From responsibility to regulation}

Citizenship 'is a weighty, monumental, humanist word' (Fraser and Gordon 1994 cited in Kabeer 2001:1), not to be used lightly or flippantly. While the idea of citizenship is nearly universal, ideas about citizenship are not. It is argued here, firstly, that the rather loose use of the term to describe the responsibilities of firms inappropriately describes community-company relations characterised by sharp power inequalities. Secondly, it is not at all clear that contemporary appropriations of citizenship discourses sit comfortably with the content of the term, traditionally understood.

Traditionally, 'citizenship expresses a set of normative expectations specifying the relationship between the nation-state and its individual members which procedurally establish rights and obligations of members and a set of practices by which these expectations can be realised' (Waters 1989 cited in Kabeer 2001:2-3). What is lacking in many contemporary uses of the term by companies is detail on procedures and practices that can make these rights real. What some contemporary uses of corporate citizenship do borrow from the origins of the term is the notion of civic virtue, making a contribution to political life and participating in social decisions and activities, that evolved from the work of the classical philosophers (Kabeer 2001). This harks back to the origins of corporate responsibility which lay in post-colonial traditions of corporate philanthropy, donating hospitals and schools to communities in return for their political acquiescence. As Amnesty note in their survey of codes of conduct, companies still refute the idea that they are responsible for human rights in the communities in which they operate, instead emphasising that 'we build schools and roads .. and provide scholarships to the needy' (Tripathi 1999). Citizenship means something different. According to Amnesty, labour standards and human rights incorporated in ILO conventions and the universal declaration of human rights 'provide the basic framework on which our society, in its broadest form, rests.' 'By endorsing it, companies are not doing something great and noble, but something they 
are obliged to do ..[this] is an example of corporate citizenship and assuming the responsibilities that go with citizenship' (ibid).

Realising this citizenship means providing an enabling environment for the exercise of rights. Material and political resources are key to the meaningful exercise of citizenship. Whereas 'the state ... enumerates the rights and responsibilities of individual citizens and gains its legitimacy from their capacity to access rules and resources of the state on equal terms' (Kabeer 2001:20-21), the legitimacy of corporations does not rest on the provision of the same degree of access. Apart from refusing to buy a product of a corporation, or buying shares in a company and thereby gaining a say in a company's behaviour as a stakeholder, there are a few channels for making companies answerable for the decisions they make, despite the impact of their investment choices on peoples' lives. The contract that employees engage in with companies is not a free one because of the economic control the company has over employees' livelihoods by choosing whether or not to employ them. The community of responsibility is also narrowed by virtue of the private deals that often characterise those social contracts that do exist in the form codes of conduct and the like. Moreover, the power of anticipated reaction works to censor rights claims for fear of driving companies away. The dependence of workers on their employers significantly reduces their negotiating leverage. Insofar as rights can be asserted in this context, they have to be fought for and cannot be taken for granted. This is a key brake to moving the corporate citizenship debate beyond 'claims based on charity, favour or patronage' (Kabeer 2001:40), to an expression of inalienable rights. Contemporary expressions of corporate citizenship do not extend to the provision of systematic access and equality of treatment, relying instead on charitable acts subject to philanthropic whim.

It becomes clear then that the demands of citizenship far outstrip what corporations are in a position to provide. Both in terms of broader duties and the provision of access, we find corporate notions of citizenship lacking, a fact which makes the entitlements that companies acquire through invoking the language of citizenship, a one-sided deal. What we may find is that new forms of public regulation provide the forms of access, entitlements and redress that are beyond corporate-led selfregulation. They may make the process of holding corporations accountable more predictable and equitable and less arbitrary.

However, relying on public arenas as the appropriate venues for the articulation of citizenships should not be the only focus of attention, as it overlooks other forms of participation as legitimate expressions of citizenship through citizen juries, protest and the like. Many examples below, illustrate the diverse ways in which people attempt to create new spaces for the construction of rights, entitlements and new notions of citizenship which serve to challenge orthodox understandings. Claiming rights through formal arenas such as courts and legislatures implies power, resources, authority and legitimacy. Inequities in these assets, particularly between companies and the communities they may be in conflict with, make mediation of rights-based claims a fundamentally political process.

What is problematic in this regard, is that much of the contemporary discourse on corporate social responsibility (CSR) seeks to depoliticise the relationship between companies and communities, governments and NGOs. The emphasis of stakeholders 
and partnership (Murphy and Bendell 1997; Long and Arnold 1995) serves to deny the conflicts that exist between actors, as well as the power asymmetries which underpin these relationships. The effect is to imply that disputes, rather than representing conflicts of values, are amenable to technical problem-solving. This bias towards partnership is perhaps explained by the management orientation of much of the CSR literature which tends to view community conflict over environmental and social issues as a management challenge to companies' traditional ways of working. The issue then becomes how to handle the conflicts in a way which least interferes with the imperative of profit accumulation. While in some settings problems may be appropriately settled through 'liberal' approaches of partnership and consensusbuilding (Newell 2001a), the emphasis on negotiation implies a position of leverage on the part of a community, which poorer groups will often not have. Moreover, in these settings, campaigns targeted at the corporate sector are as likely to be about land rights, human rights, and issues of compensation and exploitation, as a technical issue that can be subject to informed debate and round table negotiation.

Emphasis on corporate philanthropy rather than community rights may be particularly misplaced when we are dealing with regions and sectors that are isolated from many pressures to present a positive corporate image, by virtue of being further down the supply chain. Many regions of the world are beyond the 'whirl' of CSR and corporate philanthropy. They are out of the spotlight, such that the scope for damaging and irresponsible investments is vastly increased. The key factor here is the poverty of communities, however, and not whether they are located in the Northern or Southern hemispheres per se. ${ }^{3}$ Work on environmental racism shows that hazardous activities such as waste incineration and toxic waste disposal are often deliberately located in areas where there is likely to be less organised resistance, where less politicallyinfluential groups are based (Rochelau et al 1995). The poor are expected, through lack of choice, to accept more hazardous forms of employment, captured nicely in economist Joan Robinson's comment that 'there is only one thing worse than being exploited and that is not being exploited' (quoted in Strange 1988).

\section{Claiming Rights, Constructing Citizenships: Towards bottom-up corporate accountability}

If constructing meaningful corporate citizenship requires us to redress power inequities, a number of issues have to be addressed. Strategies need to be developed for questioning the bases on which companies can avoid their obligations as global citizens. Challenging the mobility that companies have acquired through technological advances and the global re-organisation of production, means building new forms of solidarity (Gaventa and Smith 1991; Seidman 1990; Waller et al 1990). For example, when Mitsubishi responded to international pressure by shutting its controversial rare earth processing plant in Malaysia, it immediately subcontracted the same work to two companies in China (Karliner 1997:200). Reflecting on similar such episodes, Gaventa notes 'increased globalisation meant that communities were affected by economic blackmail which pitted poor regions and workers against oneanother, with threats of moving jobs elsewhere if community action became too strong' (1999:28). One strategy, aimed at forging solidarities between workers in

\footnotetext{
${ }^{3}$ Gaventa's notion of 'Souths within the North' and 'Norths within the South' is helpful in this regard (1999).
} 
Mexico and in the Appalachian south, has been the organisation of study tours so that 'women who had lost their jobs in the Appalachian region could visit their counterparts who had gained similar jobs in ... the maquiladora region of Mexico' (Gaventa 1999:33). Shared experiences can be communicated through community exchanges and the making of videos which allow people to see how companies have exploited other communities. The 'No Place to Run' video, for example, told the story of Union Carbide's record in the U.S, India and other communities, and showed how the Bhopal plant was modelled after a similar Union Carbide plant that had been built in the relatively poor, primarily black Appalachian community of Charleston, West Virginia (Gaventa 1999:30).

Corporations can also evade their responsibilities on legal grounds by claiming that their subsidiaries are separate legal entities. This was the basis of the claim in the Bhopal and many other negligence cases, where the onus is on victims to provide evidence of a clear chain-of-command between home and host country, which would make the former liable for the actions of the latter. NGOs and community groups, through information exchange and coalition-building, have been able to demonstrate the irresponsibility of firms by exposing the transfer of technologies and production processes known to be hazardous to locations where protection is weaker (Newell 2001b). Hence although processes of globalisation enable companies to maintain a distance between the site of production and the site of consumption, and thereby keep from view the social and environmental consequences of their production processes, NGO networking and use of the media can ensure that local events become global spectacles in a short space of time (Newell 2000, Fabig and Boele 1999).

For a community to demonstrate that its rights have been violated is an enormous task, however, because of the power inequities that exist. Meeting high standards of scientific proof in order to validate claims makes the task even more difficult. Some groups have been able to challenge the basis of expertise which companies draw on to evade responsibilities, where, for example, scientific studies are often invoked to prove that the health of communities has not been harmed. One way of confronting the potential for a monopoly on expert knowledge is to engage in various forms of 'worker or housewife epidemiology'. Merrifield (1993) discusses attempts by communities to document the felt affects of toxic chemicals on their well-being by conducting their own household surveys of exposure to chemicals and their human consequences in the face of scepticism and non-cooperation from expert science. Such participatory health risk assessments provide an important counter-weight to orthodox assessments of industrial hazards which negate lived experience, as well as improving the confidence of communities to challenge perceived injustices through their own means.

Beyond challenging corporate power in these ways, there appear to be some factors that explain both a company's responsiveness and a community's ability to have rights heard and enforced. As was noted above, it is often the most powerful companies that will come into contact with the poorest sections of society. The mining industry, for example, operates in remote and impoverished parts of the world that are often inhabited by indigenous tribal populations. 'These indigenous groups have limited resources and in most cases feel relatively powerless in negotiating with a large corporate entity' (Ali 2000). The relative monopoly over economic development that resource extraction companies have in remote regions, means that 
'positive outcomes from negotiations may be difficult to envisage or attain' (ibid:94). Hence, whilst in global terms it tends to be larger, generally multinational, companies that are more vulnerable to campaigns because of their visibility, the scale of their operations and the resources they command, without the means to globalise a rightsbased struggle, power inequities mean that local movements may not be able to make much progress on their own.

Being part of internationalised networks can be a source of strength in this regard. International publicity can ensure that community voice in local debates is amplified and their standing enhanced. In relation to the efforts of the rubber tappers to prevent ranchers and loggers from accelerating deforestation through land clearance, Bendell and Murphy (2000:68) cite Dore, who argues: 'By the mid-1980s ...indigenous groups and tappers were considered legitimate participants in the debate. Their persistent resistance to expropriation and to felling the forest, combined with their links to national and international organisations, converted them from pariahs to legitimate actors in the unfolding drama'. The case of Shell in Nigeria suggests, however, that internationalising a campaign can often change its focus. In this case, there was a shift from, essentially a struggle over land rights and access to the profits from oil production, to a campaign that used the environment as an issue likely to generate broader concern, in order to draw attention to the case. Nevertheless, the involvement of other companies such as the Body Shop and the support of better resourced international NGOs such as Greenpeace and Amnesty helped to generate publicity and political action which $\mathrm{MOSOP}^{4}$ itself would be unable to deliver.

Internationally coordinated campaigns can also serve to expose double-standards that companies employ when operating in the South, as well as create pressures on all parts of the company, and thereby increase the likelihood of generating a response. Following the discovery of arge concentrations of highly toxic mercury in a river near Durban, an alliance of trade unions, peasant groups and green groups from a number of different countries mounted demonstrations against Thor chemicals. Mittelman concludes (1998:865) 'this joint action within civil society put pressure on the Department of Water Affairs, which ordered Thor chemicals to suspend its operations'. Shareholder activism plays on the 'hassle factor', by which part of a company's business which is of negligible overall value to its profits is targeted, but which nevertheless has a detrimental impact on the reputation of the company's other operations, providing it with a strong incentive to address the issues raised by activists (Rodman 1998; Marinetto 1998).

Partly because of this potential for global exposure, however, companies may also be wary of working too closely with an organisation that is well networked internationally. When negotiating with local communities, companies can charge that discussions are being unduly influenced by external agents. Ali, discussing negotiations between aboriginal communities and mining companies shows how 'even though a majority of the community representatives favoured the ENGO's [environmental NGO] opinions on environmental impact, the fact that they were being represented by an external entity in some ways legitimised the corporations refusal to talk to them. They were branded as the ENGO's cronies and so the mining company was able to get away with limited communications' (Ali 2000:88).

\footnotetext{
${ }^{4}$ Movement for the Survival of the Ogoni Peoples.
} 
Where businesses enjoy close relations with governments in key resource and extractive sectors such as timber, oil and mining, it is harder for communities to successfully push for recognition of their rights. In Malaysia, for example, logging reform is frustrated by the fact that key ministers responsible for environmental protection are also involved in the logging industry (Dauvergne 1996). Where the revenues generated by a company are significant, governments desperate for income tend to overlook the claims of communities that may be affected by proposed investments. The likelihood of this happening is pronounced where the rights-based claims of communities conflict with key state interests, over land for example. This is the case in recent struggles in Ecuador involving the company Texaco (Kimerling 1996, 2000). Again it should be noted that the issue is dependence on a particular industry, an issue that afflicts communities in the North and South alike. Writing about Eastern Kentucky in the U.S. and the control that the mining industry exercises with the government, Szakos notes 'Only when the state's citizens gain some measure of control over the decisions that affect them will the state's economy become more responsive to the needs of its people' (1990:36).

Clearly these are just some of the factors that seem to determine the responsiveness of corporations to the communities in which they invest, and which will strongly affect the effectiveness of future strategies for corporate accountability. What we find is that questions of power, access to resources and the conflicts these produce are key and yet remain largely absent from contemporary debates about corporate citizenship.

\section{Conclusion}

This paper has sought to interrogate the notion of corporate citizenship by comparing it with traditional understandings of the term and situating it within broader debates about accountability in development. It has been argued that the term citizenship poorly describes the current balance of rights and duties that major firms enjoy in the contemporary global political economy. Power inequities and the lack of meaningful and effective mechanisms of accountability between firms and those they work with in poorer communities, North and South, make the language of citizenship largely redundant. The challenge remains how to develop mechanisms of corporate accountability that help to provide the poor with a level of protection and the means by which to express their rights and have them enforced in settings in which firms have few incentives to think beyond business-as-usual investment practices.

\section{Bibliography}

Ali, S.H., 2000, 'Shades of Green: NGO coalitions, mining companies and the pursuit of negotiating power' Bendell, J. (ed) Terms of Endearment, Sheffield: Greenleaf Publishers pp.79-95

Bendell, J. and Murphy D., 2000, 'Planting the seeds of change: business-NGO relations on tropical deforestation' Bendell, J. (ed) Terms of Endearment, Sheffield: Greenleaf Publishers pp.65-78 
Corporate Citizenship Research Unit, 2001, Deakin University web site,

http://ww.arts.deakin.edu/au/ccr

DFID, 2000, 'Making globalisation work for the Poor' White Paper, London

Fabig, Heike and Boele, Richard. 1999, "The Changing Nature of NGO Activity in a

Globalising World: Pushing the Corporate Responsibility Agenda", IDS Bulletin, 30(3): 58-67, July 1999

Gaventa, J., 1999, 'Crossing the great divide: Building links and learning between NGOs and Community-based organisations in North and South' in Lewis,D. (ed) International Perspectives on Voluntary Action: Reshaping the Third Sector London: Earthscan.

Gaventa, J. and Smith, B., 1991, 'The de-industrialisation of the textile South: A case study' in Leiter, J. Schulman, M. and Zingraff, R. (eds) Hanging by a Thread: Social Change in Southern Textiles, Ithaca New York: Ithaca Press

Gill, S., 1995, 'Theorising the interregnum: The double movement and global politics in the 1990s' in Hettne, B. (ed.) International Political Economy: Understanding Global Disorder, London: Zed Books

Goetz, A.M. and Gaventa, J., et al, 2001, 'ringing Citizen Voice and Client Focus into Service Delivery', IDS Working Paper 138, Brighton: IDS

Goetz, A.M. and Jenkins, R., 2001, 'Hybrid forms of accountability: Citizen engagement in institutions of public sector oversight in India', Public Management Review Vol. 3, Number 3, September

Hathaway, D., 1993, 'Grass-roots politics vs. Capital: The Tri-state conference on steel', $\underline{\text { Can }}$ Workers Have a Voice? The Politics of De-Industrialisation in Pittsburgh, Pennsylvania: Pennsylvania State University Press, pp.91-131

Jones, E. and Gaventa, J., 2001, 'Concepts of Citizenship: A Review', DRC draft paper, September $1^{\text {st }}$

Kabeer,N., 2001, 'Citizenship and the boundaries of the imagined community: Identity, affiliation and exclusion', DRC draft paper

Kimerling, J. 1996, 'Oil, lawlessness and indigenous struggles in Ecuador's Oriente', in Helen Collinson (ed), (1996), Green Guerillas: Environmental Conflicts and Initiatives in Latin America and the Caribbean, London: Latin America Bureau

Kimerling, J., 2000, 'The story from the oil patch: The under-represented in Aguinda V Texaco', Human Rights Dialogue, pp. 6-7

Long, F.J. and Arnold, J. (1995) The Power of Environmental Partnerships Management Institute for Environment and Business

Mabey, N., 1999 'Defending the legacy of Rio: The civil society campaign against the MAI' in Picciotto,S. and Mayne,R. (eds) Regulating International Business: Beyond Liberalisation Basingstoke: MacMillan. 
Marinetto, Michael, 1998, "The Shareholders Strike Back - Issues in the Research of Shareholder Activism", Environmental Politics, 7(3): 125-133

Merrifield, J., 1993, 'Putting scientists in their place: Participatory research in environmental and occupational health', in Park,P. Brydon-Miller,M. Hall,B. and Jackson,T. (eds) Voices of Change: Participatory Research in the United States and Canada, Toronto: OISE Press

Mittelman, J., 1998, 'Globalisation and Environmental Resistance Politics', $\underline{\text { Third World }}$ Quarterly 19(5): 847-872

Murphy, D. and Bendell, J., 1997, In the Company of Partners, Bristol: Policy Press, pp. 105130

Newell, P., 2000a, 'Globalisation and the new politics of sustainable development' in Bendell, Jem (ed.) NGOs and Sustainable Development, Greenleaf Publishing Ltd: Sheffield

Newell, P., 2000b, 'Environmental NGOs and Globalisation: The governance of TNCs', Cohen, R. and Rai, S. (eds) Global Social Movements, London: Athlone Press, pp117-134

Newell, P. 2001a, 'Managing Multinationals: The Governance of Investment for the Environment', Journal of International Development Vol.13, 2001

Newell, P., 2001b, 'Access to environmental justice? Litigation against TNCs in the South', IDS Bulletin Vol. 32 No 1

Rodman, K., 1998, 'Think Globally, Punish Locally: Non-state Actors, MNCs and Human Rights Sanctions', Ethics and International Affairs 12

Schedler, A.D.L. and Plattner, M., 1999, The Self-restraining State: Power and Accountability in New Democracies, Lynne Rienner Publishers: Boulder and London

Scholte, 2000, Globalisation: A Critical Introduction, Basingstoke: MacMillan

Seidman, A., 1990, 'The changing international division of labour: Links with Southern Africa', in Gaventa,J. Smith,B. and Willingham,A. (eds) Communities in Economic Crisis: Appalachia and the South, Philadelphia: Temple University Press

Strange, S., 1988, States and Markets, London: Pinter Press

Strange, S., 1996, The Retreat of the State, Cambridge: Cambridge University Press

Szakos, K.L., 1990, 'People power: Working for the future in the East Kentucky coalfields', in Gaventa, J. Smith, B. and Willingham, A. (eds) Communities in Economic Crisis: Appalachia and the South, Philadelphia: Temple University Press.

Tripathi, S., 1999, 'Codes of conduct for businesses', Amnesty International, speech at Corporate Social Responsibility conference, RIIA, London. Text available at: http://web.amnesty.org 
Waller, M., Lewis, H. McBrien, C. and Wessinger, C., 1990, 'It has to come from the people': Responding to plant closings in Ivanhoe, Virginia', in Gaventa, J. Smith, B. and Willingham, A. (eds), Communities in Economic Crisis: Appalachia and the South ,Philadelphia: Temple University Press

Zadek, Simon, Pruzan, Peter and Evans, Richard (eds), 1997, Building Corporate AccountAbility: Emerging Practices in Social and Ethical Accounting, Auditing and Reporting, Earthscan Publications, London

Zadek, S., 2001, The Civil Corporation: The New Economy of Corporate Citizenship London: Earthscan. 